\title{
ЛИНГВИСТИЧКИ АСПЕКТИ ФИЛОЗОФСКЕ МИСЛИ ЉУБОМИРА НЕДИЋА (1858-1902)**
}

\begin{abstract}
Филозофска мисао Љубомира Недића која стоји у непосредној вези са лингвистиком може се класификовати у две тематске целине: 1) опис основних одлика појма као логичке категорије у односу на реч као категорију граматичког система, и 2) опис логичке представе суда у односу на лингвистичку представу реченице. У раду се износе и анализирају филозофски погледи Љ. Недића која стоје у вези са обе изложене целине, а затим се разматра значај тих погледа за српску лингвистику с краја 19. века.
\end{abstract}

Кључне речи: историја српске филозофије, историја српске лингвистике, Љубомир Недић.

\section{Увод}

1.1. Међу српским филозофима који се на прелазу из 19. у 20. век баве теоријом лингвистике нарочито се истиче име Љубомира Недића, професора логике на Великој школи и потоњег књижевног критичара. ${ }^{1}$ Недић је под

*nenad.ivanovic@isj.sanu.ac.rs

** Овај рад је настао као резултат финансирања Министарства просвете, науке и технолошког развоја Републике Србије, према уговору бр. 451-03-68/2020-14/200174. Лингвистичка истраживања теоријске базе савременог српског језика, спроведена у раду, изведена су као саставни део посла на изради Речника срйскохрвайског књижевног и народног језика САНУ.

1 Љубомир Недић (1858-1902), филозоф, књижевни критичар. Студирао је у Јени: најпре још неутврђену научну област (1874-1878), па медицину и биологију (1878-1880), одакле прелази на студије психологије и логике у Лајпцигу (1880), Берлину и Лондону (1880-1884). Године 1884. у Лајпцигу Љ. Недић код оснивача експерименталне психологије В. Вунта брани докторску дисертацију под насловом Учење о квантификацији предиката у новијој енглеској логищи. Дисертација је штампана 1886. на немачком у Вунтовом часопису Philosophische Studien, a у потпуности је објављена на српском језику тек 2000. године (Недић 2000: 5-39). По повратку у земљу Љ. Недић предаје логику на Великој школи (1884-1895), као четврти предавач ове дисциплине код нас (после К. Бранковића, М. Кујунџића и А. Васиљевића). Из тог времена потиче рукопис бележака са Недићевих предавања из логике и психологије, који је први пут у целини штампан 2000. године (Недић 2000: 141-280 (логика) и 281-317 (психологија)) (према: Марић 2000). 
утицајем научних токова свог доба, пре свега Вунтових схватања о језику, изнео науци о језику у то време непознате погледе на природу и састав језичког система. Ови погледи су припремили терен за појаву савремених универзитетских лингвиста - међу првима А. Белића - који се у својим делима отворено позивају на филозофско наслеђе које им претходи.

1.2. Главни део своје мисли о језику Недић је формирао у деветој деценији 19. века: најпре као докторанд код Вилхелма Вунта, ${ }^{2}$ са тезом о квантификацији предиката у новијој енглеској логици, а затим и као професор на Великој школи, са предавањима из појмовне логике. ${ }^{3}$ У овим предавањима Недић наставља рад својих претходника К. Бранковића и М. Кујунџића на односу између логичких и језичких категорија. ${ }^{4}$ Посматран у овом контексту, Љ. Недић чини део линије српских логичара на Великој школи који језику постепено дају теоријску аутономију у односу на филозофију, издвајајући га међу засебне научне феномене и придајући му властити аналитички апарат.

По месту које заузима у српској логици, Недићева мисао је најпрогресивнија у оном делу у коме се укршта са лингвистиком. Као и његови претходници, и Недић одређује логику као „начин на који мишљење долази до истине", али, за разлику од њих, он у то одређење убраја и језик као план изражавања мишљења. Два од три традиционална облика логичког мишљења, појам, суд и закључак, тиме добијају своје лингвистичке еквиваленте: појму на плану израза одговара реч, а суду - реченица (другим речима: појмовним категоријама на плану израза одговарају лексичко-граматичке, а логичким - синтаксичке). Еквиваленција појма и речи, односно суда и реченице чини основ Недићевог разумевања односа филозофије и лингвистике.

1.3. Имајући ово у виду, у раду ћемо анализирати Недићеве логичке представе појма и суда у односу према језичким представама речи и реченице. Циљ нам је да покажемо начин на који Недић развија аутономну лингвистичку мисао и пратећу терминологију, као и да истражимо утицај који су његова размишљања о језику имала на развој српске лингвистике крајем 19. и почетком 20. века.

\footnotetext{
${ }^{2}$ Вилхелм Вунт (1832-1920), филозоф, филолог, експериментални психолог. У повести лингвистике В. Вунт ће остати запамћен по вишетомном делу Völkerpsychologie, у коме разматра језик системски, као кључ начина на који функционише људски ум. Српску филозофију и лингвистику В. Вунт је задужио и тиме што је, током своје научне каријере, био ментор већем броју српских научника који су, израђујући докторске тезе под његовим надзором, стицали савремена научна знања из ових области. Пун допринос В. Вунта српској, па и светској науци о језику остао је до данас неистражен (према: Костић 2006: 25-27).

3 Уџбеник логике Љ. Недића није објављен за његовог живота, иако Недићеви рукописи из овог предмета, сачувани у Универзитетској библиотеци и приређени за штампу 2000. године од стране И. Марића, говоре о томе да је Недић из ове области имао, практично, готову књигу. Тачна година настанка Недићевих предавања није позната. Она се везују за крај осме деценије 19. века (Жуњић 2014: 195).

${ }^{4}$ Константин Бранковић (1814-1865), аналитички филозоф, педагог. У деловима својих студија Основно мудрословље (1848) и Мислословље или логика (1851) који су посвећени појму К. Бранковић је дао теоријску и терминолошку основу за савремено проучавање односа логике и лингвистике на нивоу речи. На његов рад надовезује се дело филозофа Милана Кујунџића

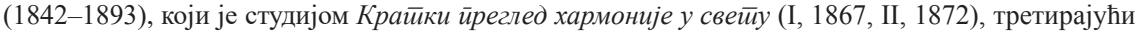
језик као говор, проширио дату основу у кључу натурализма и лингвистичког психологизма. У филозофском делу Љ. Недића видљиви су утицаји оба његова претходника.
} 


\section{Филозофска мисао Љ. Недића о односу појма и речи}

2. О питању односа појмова и речи Недић је најопширније писао у првој целини своје Логике, под насловом Елементарни облици и закони логичког мишљења. Тај однос он развија кроз више смисаоних целина: 1) појам у логичком смислу и реч у лингвистичком смислу: сродности и разлике; и 2) сродност између јединица логичког мишљења и изражавања; 3) однос логичког садржаја појмова према морфолошким обележјима речи; 4) разлика која постоји између појмова у логичком смислу у односу на разлику између речи у лингвистичком смислу.

2.1. У представљању појма у логичком према речи у лингвистичком смислу Недић уводи модел који садржи: појам као експонент логичког мишљења, затим, ствар као категорију предмета на коју то мишљење упућује, и реч као посредника између појма и ствари. Однос између речи, појма и ствари Недић одређује тврдњом да су „речи представници појмова, као што су појмови представници ствари и једно друго заступа" (Недић 2000: 173). Овом дефиницијом поставља се хијерархијски однос елемената у моделу: ствари стоје у вези са појмовима који апстрахују њихова стална обележја, док речи изражавају ове апстракције у комуникацији.

2.2. Сродност између јединица логичког мишљењ а и изражавања Недић наглашава тиме што тврди да основној класификацији појмова у формалној логици одговара класификација речи у граматици. Појмови се деле на категорематичне и синкатегорематичне, према томе могу ли или не самостално улазити у састав логичких судова, а овом у граматици одговара подела речи на самосталне и несамосталне, према томе могу ли или не стајати у својству субјекта или предиката у реченици. У самосталне речи Недић убраја именице, придеве, заменице и глаголе, а у несамосталне предлоге, прилоге и везнике (Недић 2000: 179). ${ }^{5}$

2.3. Недић повезује логички садржај појмова са морфолошким обележјима речи тиме што дефинише четири класе у које се могу сврстати сви појмови и све речи. То су: класа предмета, затим класа особина, класа радњи или стаға, и класа односа. На плану израза, предметима одговарају именице, особинама - придеви, радњама или стањима - глаголи, и односима - везници, предлози и прилози (Недић 2000: 179-182). Граматичке класе речи, дакле, представљају резултат формализације општих својстава појмова које представљају. У том смислу, разумљиво је то што љ. Недић на овом месту не наводи раније поменуте заменице - које ће нпр. Јесперсен, три деценије касније, уврстити у своју, иначе истоветну класификацију речи по логичким категоријама, изведену у студији Филозофија граматике. Разлог за овај Недићев поступак по свој прилици лежи у природи прономинализације која је

\footnotetext{
${ }^{5}$ Интересантно је то што се ова, синтаксички мотивисана класификација речи по врстама не налази у граматикама тог времена које је Недић могао да консултује. Тако мотивисану поделу (којој је придодата класа бројева као променљивих речи) срећемо тек у Српској граматиции С. Новаковића из 1894 (Новаковић $1894^{2}$ [1902]: 10-22).
} 
(како то Јесперсен и сам истиче) зависна од онога на кога или на шта заменице упућују, и стога хетерогена (Јесперсен 1925 [1951]: 82-86).

2.4. После излагања о сродностима између појмова и речи, Недић прелази на опис њихових разлика. Основна разлика између појмова у логичком смислу у односу на разлику између речи у лингвистичком смислу је у томе што речи, за разлику од појмова, у себи садрже две логичке категорије: категорију предмета, на коју упућују својим семантичким садржајем, и категорију односа, на коју упућују својом флексијом. Под флексијом Недић подразумева сваку морфосинтаксичку или деривациону одлику која утиче на односе између речи у реченици. Тако, на пример, Недић у флексију подједнако убраја облик инструментала именице нож (ножем) и предлог с уз инструментал (с ножем) (Недић 2000: 180). ${ }^{6}$

Недић даље тврди да категорија односа као својство речи да долази у везу са другим речима утиче на њену лексикализацију. Као пример наводи глаголски партицип (типа изабран, изгнан и сл.) који показује да је реч из класе стаға прешла у класу особина. Појаву да се речи својим граматичким категоријама прилагођавају оним логичким Недић заједно са Вунтом назива категоријалним помицағем појмова (Недић 2000: 181). Пола века након Недићевог курса логике, такође се позивајући на Вунта, А. Белић ће дефинисати системске одлике овог процеса у историји језичког развитка - нпр. постанак придева од глагола и од именица (Белић $1958^{2}$ [1998]: 39-52 и д.).

Опсервације Љ. Недића изнете на овом месту у Логищи не остају само у домену теорије. Ослањајући се на категорију односа, Недић износи и актуелна запажања о развоју европских језика. По њему, постоје језици у којима се односи изражавају наставцима (данас бисмо рекли: синтетички језици), и језици у којима се односи изражавају синтаксички, „нарочитим речима, предлозима и т. д.” (данас бисмо рекли: аналитички језици). Српски језик Љ. Недић убраја у синтетичке, са тежњом ка аналитизацији, у којој види виши ступањ развитка језика као израза мисли (Недић 2000: 180-181). ${ }^{7}$

2.5. Недић у својој Логици даље представља четири главне врсте односа између појмова: однос идентитета, затим однос супсумиије (појмовног обухватања или садржавања), однос координащије (појмовне сродности, односно различитости) и однос негащије. Сва четири описана типа односа имају своје лингвистичке еквиваленте: тако се нпр. однос супсумщије на лексичком плану разматра као однос хипонимије, однос координације као однос синонимије и антонимије и др. Међутим, Љ. Недић у Логищи лингвистички обрађује само први, однос идентитета.

\footnotetext{
${ }^{6}$ Као што се из приложеног види, Недићево тумачење појма флексије шире је од традиционално лингвистичког. Оно се заснива на односима између речи, а не на њиховој морфологији. Овакво тумачење флексије најближе је лингвистици функционалистичког усмерења која је базирана на синтакси (Ивић М. 2001 (1): 175-178).

${ }^{7}$, „Код нас у врло маленом броју дозвољава се употреба садашњег времена [глагола] у смислу придева ... У Немачком језику нема никаквог зазора од овакве употребе ... Код нас је то теже, у нашем језику није се у стању увек са прецизношћу свака мисао исказати, као у Немачком језику, а најбоље се то може у Енглеском језику који [је] најсавршенији у погледу синтактичком а најсиромашнији у облицима (флексији)” (Недић 2000: 181-182).
} 
План односа између садржаја појмова и речи Љ. Недић представља исказом човек је човек, којим се у логици наглашава да је појам човека истоветан за сва времена и све контексте у којима се употребљава. Са друге стране, на плану израза копулативна реченица Човек је човек представља номиналну таутологију, у којој предикатски члан има другу граматичку класу од субјекатског члана. ,Често се каже: 'Човек је човек'. Ми нећемо тиме да кажемо да је човек једно биће које је идентично са самим собом ... него хоћемо да кажемо да је човек слабо биће, може да погреши и т. д. ... У овом случају под речју човек ми разумемо ... једну од особина што придајемо човеку" (Недић 2000: 183, курзив: Н. И.). Реч особина важна је јер сугерише да човек у предикату има придевску вредност. Овај пример потврђује и то да категорија односа у српском језику за Недића није искључиво везана за синтетичка обележја речи, већ и за њихове конституентске вредности у реченици и значењске односе са другим реченичним члановима.

\section{Филозофска мисао љ. Недића о односу суда и реченице}

3. За разлику од односа речи према појму, однос суда према реченици Недић разрађује кроз јединствени модел заједнички и за план логике и за план лингвистике. Тај модел је састављен од субјекта, као дела суда који садржи појам о коме се суди, затим, предиката као појма који садржи оно што се о субјекту суди, и копуле као речце ,jе” која спаја и везује субјекат и предикат (у лингвистици: подмет, прирок и спона). Суд или реченица по Недићу је акт мишљења који обележава спајање, путем копуле, неког познатог појма у субјекту са новим појмовним садржајем у предикату који га спецификује или детерминише (Недић 2000: 189-190).

3.1. Еквиваленција суда и реченице видљива је најпре у чињеници да у логици постоје ставови који садрже само један члан модела, а њима у језику одговарају реченице са елидираним чланом које се сматрају граматички потпуним исказима. Љ. Недић овде говори о два типична случаја: о судовима без субјекта, којима одговарају реченице са безличним глаголом у предикату (типа Свиће, Дува и др.), и о судовима без предиката, којима одговарају реченице у којима субјекат представља пуну структуру (типа Bampa!, Пожар! и др.). Позивајући се на логичку аргументацију, љ. Недић даље настоји да расправи питање: да ли у овим судовима/реченицама други члан постоји, али није формално исказан, или не постоји у дубинској равни исказа. У односу на поменуто питање Љ. Недић разликује, и одваја, судове/реченице које су формално без субјекта и без предиката. Судови/реченице без субјекта (Свиће, Дува) су самосталне јединице у којима се субјекат не подразумева. Са друге стране, судови/реченице без предиката (Baтра!, Пожар!) чине скраћене изразе за потпуне судове/реченице, и у њима предикат мора бити имплициран. Као доказ за ово Љ. Недић наводи аргумент да, логички гледано, судови са елидираним субјектом (односно, недостајућим дефиниенсом) представљају 
констатације, а судови са елидираним предикатом (односно, недостајућим дефиниендумом) - непотпуне дефиниције (Недић 2000: 192-193). ${ }^{8}$

3.2. Ослањајући се на реченицу као врсту вербално логичког суда, Љ. Недић у расправу о односу суда и реченице уводи ставове енглеских логичара, Мила и Хамилтона, о суду као квантификацији предиката. Љ. Недић констатује да се код већине судова предикат не користи у свим могућим значењима, тј. да се користи само партикуларно у односу на субјекат. Тако нпр. суд сви су људи смртни, логички потпуно исказан, требало би да гласи сви су људи неки смртни (нека смртна бића) (Недић 2000: 199). Потврду за ово Љ. Недић налази у аргументу да предикат реченице сви су људи смртни укључује и квантитет, односно, да номинализовани придев смртни у предикату може бити схваћен и као парцијалност појмовног садржаја (,partielle”, неки смртни) и као тоталитет појмовног садржаја (,totale”, сви смртни). ${ }^{9}$ У контексту овог питања, тачка разилажења суда и реченице била би у томе што логичар, код сваког суда, треба да експлицира то да ли је предикат са свим својим примерима афирмисан или негиран субјекту, или само са неким примерима; док говорник природног језика није у стању да то учини. Неексплицирање појмовног садржаја предиката у логичким судовима представља, по Љ. Недићу, грешку коју логичари чине поводећи се за језиком (Недић 2000: 200).

\section{Закључак}

4.1. У српској лингвистици, досадашња истраживања научног дела Љ. Недића тицала су се углавном његове нормативне, тј. правописне компетенције. У науци је истакнуто да Недићева расправа O правопису и интерпункцији из 1894. године ${ }^{10}$ представља озбиљну студију која показује сву дубину српских правописних проблема и заузима важно место међу сродним студијама у 19. веку (Брборић 2017: 326). Са друге стране, сматрамо да све што је изложено у овом раду указује на потребу да се Недићева лингвистичка

\footnotetext{
${ }^{8}$ Поменути аргумент Љ. Недић износи у контексту филозофско-лингвистичке расправе с краја 19. века о (не)постојању имплицитног субјекта/предиката у бесубјекатским/беспредикатским реченицама. Излажући аргументе обе стране и позивајући се на Миклошићево истраживање старословенске синтаксе које потврђује да је предикат, у историјском смислу, старија појава од субјекта, Љ. Недић закључује: „Ма у ком се смислу ово питање расправило, било у оном у коме су Логичари заступали своје гледиште, било у смислу Миклошића и његових следбеника, мислим, да је поглавити део сваког суда предикат, а не субјект, у толико, у колико без предиката не може бити суда а без субјекта може" (Недић 2000: 192, истицање: Н. И.). Ово Недићево мишљење одступа од оног у традиционалној синтакси, где се бесубјекатске и беспредикатске реченице обично представљају на исти начин.

${ }^{9}$ Поред мањег дела Недићеве Логике, овом питању посвећен је главни и највећи део његове докторске тезе о квантификацији предиката. Квантификација предиката у односу на субјекат, изведена у енглеској логици половином 19. века, увела је нови, дедуктивно-аналитички приступ логици (базиран на семантици односа парцијалности и тоталитета) у аристотеловски устројен систем логичких категорија (према: Фогелин 1976).

${ }^{10}$ Спис Љ. Недића О правопису и интерпункиији представља „предлог књижевно-уметничкој заједници поднесен 8. априла 1894.” Реч је о предлогу решења књижевних спорова проистеклих из различите примене Вукових интерпункцијских и правописних правила (Брборић 2017: 326).
} 
мисао сагледа дубље, кроз генезу његове филозофске мисли. Верујемо да, у овом контексту, тек предстоје шире анализе Недићевих научних ставова о језику и језичким питањима.

4.2. Љ. Недић је последњи у низу професора логике на Великој школи који су, током друге половине 19. века, у свој предмет постепено уносили лингвистичке погледе. Ослањајући се на наслеђе својих претходника, Константина Бранковића и Милана Кујунџића, као и на учење Вилхелма Вунта, ${ }^{11}$ Недић је изградио појмовно-логички опис основних јединица језика: речи и реченице. Главна одлика овог описа је у томе што је изведен логичком дедукцијом, али на основу реалних, семантичких и граматичких критеријума који су својствени плану језичког израза.

4.3. Везујући системност логичког поступка за природна својства језика, и указујући на отклон лингвистичких категорија од логичких, Љ. Недић је на самом крају 19. века поставио подлогу за важна питања српске лингвистике и правце њеног развоја у 20. веку.

\section{ИЗВОР}

Недић, Љубомир (2000). Љубомир Недић - филозофски списи. Приредио Илија Марић. Београд: Плато.

\section{ЛИТЕРАТУРА}

Белић 1958 [1998]: А. Белић, О језичкој природи и језичком развитку. Лингвистичка испитивања, књ. 2, Београд: Завод за уџбенике.

Брборић 2017: В. Брборић, Правописна стабилност српског језика и утицај језика у окружењу, Научни састанак слависта у Вукове дане, 46/1, 323-333.

Вунт 1904: W. Wundt, Völkerpsychologie, Eine Untersuchung der Entwicklungsgesetze von Sprache, Mythus und Sitte, Erster Band-Die Sprache (2. Auflage), Leipzig: W. Engelmann.

Вунт 1922: W. Wundt, Völkerpsychologie, Eine Untersuchung der Entwicklungsgesetze von Sprache, Mythus und Sitte, Zweiter Band-Die Sprache (4. Auflage), Leipzig: W. Engelmann.

Жуњић 2013: С. Жуњић, Прирок и суштаство. Историја појмовне логике код Срба, књ. 3, Београд: Службени гласник.

\footnotetext{
${ }^{11}$ Иако близак Вунтовим ставовима и теорији, Љ. Недић као филозоф језика остаје оригиналан. Према хроничару његовог филозофског дела, С. Жуњићу, лингвистички аспекти Недићеве филозофске мисли ,,јасно изражавају његово ауторско схватање појединих отворених питања (однос језика и појмова, питање могућности ставова без субјекта итд.)” и тиме су одраз „његовог општег ауторског става и синтетичког напора" (Жуњић 2013: 246).
} 
Жуњић 2014: С. Жуњић, Историја српске филозофије, Београд: Завод за уџбенике.

Ивић М. 2001: М. Ивић, Правцุи у лингвистиции, књ. 1, Београд: ХХ век.

Јесперсен 1925 [1951]: O. Jespersen, The Philosophy of Grammar, London: Allen\&Unwin.

Костић 2006: А. Костић, Когнитивна психологија, Београд: Завод за уџбенике.

Марић 2000: И. Марић, Филозоф Љубомир Недић, у: Љубомир Недић - филозофски списи, Београд: Плато, 321-373.

Недић 1894: Љ. Недић, О правопису и интерпункцији - предлог Књижевно-уметничкој заједници, поднесен 8. априла 1894, у: Љ. Недић (s.a.), Целокупна дела, књ. 1, Београд: Народна просвета, 221-242.

Новаковић 1894 2[1902]: С. Новаковић, Сриска граматика, Београд: Државна штампарија.

Пипер и др. 2005: П. Пипер и др., Синтакса савременога српског језика. Проста реченица, Београд: Институт за српски језик САНУ - Београдска књига - Матица српска.

Ристић 1938: С. Ристић, Логика за школску и приватну употребу, Београд: Књижарница Радомира Д. Ћуковића.

Стојковић 1972: А. Стојковић, Развитак философије у Срба (1804-1944), Београд: Слово љубве.

Фогелин 1976: R. J. Fogelin, Hamilton's Quantification of the Predicate, The Philosophical Quarterly, Oxford: Oxford University Press.

\author{
Nenad Ivanović \\ LINGUISTIC ASPECTS OF PHYLOSOPHICAL THOUGHT OF LJUBOMIR NEDIĆ \\ $(1858-1902)$
}

Summary

Phylosophical thought of Serbian logician and literary critic Ljubomir Nedić (1858-1902) which relates to the field of linguistics can be divided into two thematic wholes: 1) the description of the logic category of notion as opposed to the linguistic category of word, and 2) the logic representation of judgement in relation to the linguistic representation of sentence. In this paper we analyze philosophical views of Ljubomir Nedić in relation to the two abovementioned wholes. Then we proceed to consider the significance of Nedić's scientific views in the context of the Serbian linguistics at the end of the $19^{\text {th }}$ century.

Key words: history of Serbian philosophy, history of Serbian linguistics, Ljubomir Nedić. 